\title{
IAEA's DEEP in Carlsbad: co-producing energy and water in Southern California
}

\section{Geoffrey Rothwell}

Department of Economics

Stanford University

Stanford, CA 94305-6072, USA

E-mail: rothwell@stanford.edu

\begin{abstract}
The joint production of energy and desalinated water is examined in the context of the construction of a Reverse Osmosis (RO) plant at the site of the (fossil-fired) Encina Power Station in Carlsbad, California. The first part of the paper reproduces cost estimates of water at the Carlsbad Desalination Project. The second part of the paper reproduces these cost estimates using the International Atomic Energy Agency's Desalination Economic Evaluation Program (DEEP). The paper shows that the cost of desalinating water with nuclear power is cheaper than at fossil-fired plants, given the high cost of fossil fuel. Further, the estimated costs of producing electricity and water with gas reactors and gas turbines are lower than light water reactors with steam turbines. The paper concludes by suggesting that the next step in nuclear desalination in the USA would be to construct an RO plant at an existing light water reactor.
\end{abstract}

Keywords: desalination economics; electricity economics; nuclear power economics; hydrogen economics.

Reference to this paper should be made as follows: Rothwell, G. (2007) 'IAEA's DEEP in Carlsbad: co-producing energy and water in Southern California', Int. J. Nuclear Desalination, Vol. 2, No. 3, pp.265-279.

Biographical notes: Geoffrey Rothwell received his Masters degrees (Economics, 1981 and Jurisprudence and Social Policy, 1984) and his PhD from the University of California, Berkeley (Economics, 1985). He began teaching at Stanford University in 1986. He is currently the Director of Honours Programmes in the Department of Economics and the Associate Director of the Public Policy Programme, Stanford University. He has published dozens of articles on nuclear power economics. He has been working on the economics of Generation IV nuclear energy systems since 1999 and is currently a member of the Economic Modeling Working Group of the Generation IV International Forum. 


\section{Introduction: desalination in San Diego County, home of General Atomics}

In analysing the international market potential for desalinated water, Bogart and Schultz (2004) of General Atomics find that situations where desalination is competitive are:

1 in those areas where there is no other option

2 where desalination plants can be sited near a coastline

3 where there are the financial resources to make desalination affordable

4 in areas that have a sufficient need and the financial resources to proceed.

They conclude, "The remaining regions that do not satisfy criteria 1-3 but satisfy criterion 4 are the Southwest North American continent and, interestingly, many parts of northern and southern Europe" (p.4).

One area that satisfies criteria 2, 3, and 4 is Southern California. One of the fastest growing counties in Southern California (and in the USA) is San Diego County. Further:

- the county relies on imported water from the California Water Project and the Colorado River

- over $90 \%$ of the county's population lives 30 minutes from the Pacific

- median household income was $\$ 46,000$ in 2000

- the county's Metropolitan Water District (MWD) is committed to subsidising desalinated water from a proposed desalination plant in Carlsbad, California.

In addition, San Diego County has the technical resources to develop affordable desalination technology. According to Dougherty (2004, p.1): "Modern desalination technology came out of General Atomics in the 1970s and was spun off into a number of smaller companies that make components for just about every step of the desalination process".

Carlsbad, California (in north central San Diego County) will soon be the home of the largest desalination plant in California: the Carlsbad Desalination Project (CDP). The CDP will be able to deliver $190000 \mathrm{~m}^{3} /$ day (or 50 million gallons per day, mgd) of water, using Reverse Osmosis (RO) technology with a salinity of 250-350 ppm (parts per million), below the World Health Organization standard for drinking water at $500 \mathrm{ppm}$ (City of Carlsbad, 2005, pp.1-4).

Will RO desalination be affordable in San Diego county? The construction cost of the CDP is approximately $\$ 272 \mathrm{M}$ (million) (2003 dollars). Assuming a 20-year life, a $90 \%$ capacity factor, and a 9\% discount rate (implying a Capital Recovery Factor (CRF) or Fixed Charge Rate (FCR) of $11 \%$ ), the capital cost of the desalination facility would be about $\$ 0.479 / \mathrm{m}^{3}$ (see Table 1).

The CDP will be co-located with the Encina Power Station, an old five-unit fossilfired steam-turbine generating plant with a net dependable capacity of $965 \mathrm{MW}$ (see Table 2). The desalination facility will use some of the power plant's discharged cooling water (about $3 \mathrm{M} \mathrm{m}^{3}$ with a salinity of $33500 \mathrm{ppm}$ ). It will blend output brine with the 
remaining discharged cooling water (resulting in a salinity of $38000 \mathrm{ppm}$ ) before releasing it to the Pacific, thus reducing the cost of constructing pretreatment and discharge facilities and reducing the environmental impact of the discharge. Further, the power plant's discharged water is approximately $30^{\circ} \mathrm{C}$, i.e., on average $5^{\circ} \mathrm{C}-15^{\circ} \mathrm{C}$ warmer than ocean water (depending on the time of year). The warmer water requires a $5 \%-8 \%$ lower feed pressure for RO separation, reducing energy costs to the desalination plant (Voutchkov, 2005).

Table 1 Construction costs and capital costs for Carlsbad Desalination Plant

\begin{tabular}{|c|c|c|c|c|c|c|}
\hline \multirow{2}{*}{\multicolumn{2}{|c|}{$\begin{array}{l}\text { Economic life of initial RO plant } \\
\text { Cost of RO plant }\end{array}$}} & \multicolumn{5}{|c|}{20 years (upgrade every 20 years for 60 years) } \\
\hline & & \multicolumn{2}{|c|}{$\$ 272$ M (2003 dollars) } & \multicolumn{3}{|c|}{ (from Chaudhry, 2003) } \\
\hline \multicolumn{2}{|c|}{ Capacity factor of RO plant } & \multicolumn{2}{|c|}{$90 \%$ annual } & & & \\
\hline \multicolumn{2}{|l|}{ Capacity } & \multicolumn{2}{|c|}{ Value in units/day } & \multicolumn{3}{|c|}{ Value in units/year } \\
\hline \multicolumn{2}{|c|}{ Size of RO plant in $\mathrm{m}^{3}$} & \multicolumn{2}{|c|}{$189 \mathrm{~K} \mathrm{~m}^{3} /$ day } & \multicolumn{3}{|c|}{$62.218 \mathrm{M} \mathrm{m}^{3} / \mathrm{yr}$} \\
\hline Size of RO pla & gallons & $50 \mathrm{Mg}$ & & \multicolumn{3}{|c|}{$16436 \mathrm{M} \mathrm{g} / \mathrm{yr}$} \\
\hline \multicolumn{2}{|c|}{ Size of RO plant in acre-feet } & \multicolumn{2}{|c|}{153 acre-feet/day } & \multicolumn{3}{|c|}{50441 acre-feet/yr } \\
\hline \multirow[b]{2}{*}{ Discount rate } & \multirow[b]{2}{*}{ Value $(\%)$} & \multirow[b]{2}{*}{$F C R(\%)$} & \multirow{2}{*}{$\begin{array}{c}\text { Fixed cost } \\
\$ / y r(M)\end{array}$} & \multicolumn{3}{|c|}{$F C$} \\
\hline & & & & $\$ / m^{3}$ & $\$ / k g a l$ & $\$ /$ acre-foot \\
\hline$r(i)=$ & 3 & 6.7 & 18.28 & 0.294 & 1.112 & 362 \\
\hline$r(i)=$ & 5 & 8.0 & 21.83 & 0.351 & 1.328 & 433 \\
\hline$r(i)=$ & 6 & 8.7 & 23.71 & 0.381 & 1.443 & 470 \\
\hline$r(i)=$ & 8 & 10.2 & 27.70 & 0.445 & 1.686 & 549 \\
\hline$r(i)=$ & 9 & 11.0 & 29.80 & 0.479 & 1.813 & 591 \\
\hline$r(i)=$ & 10 & 11.7 & 31.95 & 0.514 & 1.944 & 633 \\
\hline$r(i)=$ & 12 & 13.4 & 36.42 & 0.585 & 2.216 & 722 \\
\hline $\mathrm{r}(\mathrm{i})=$ & 15 & 16.0 & 43.46 & 0.698 & 2.644 & 862 \\
\hline
\end{tabular}

The desalination plant and offsite pump station will require an average of $30 \mathrm{MW}$ (with a peak demand of $36 \mathrm{MW}$ ), ${ }^{1}$ implying $292 \mathrm{~m}^{3} / \mathrm{MWh}$. The CDP plant will purchase this electrical power from the local electric utility (San Diego Gas \& Electric (SDG\&E)), or a power generator, broker, or seller, including Encina, owned by NRG Energy (City of Carlsbad, 2005, 4.11-17). At a cost of electricity of \$40/MWh (Chaudhry, 2003), the Energy Cost (EC) to desalinate would be $\$ 0.137 / \mathrm{m}^{3}$ (see Table 3).

Assuming O\&M costs of $19 \%$ (equal to $7 \%$ for Maintenance, $5 \%$ for Membrane Replacement, $4 \%$ for Salaries, and 3\% for Chemicals (Chaudhry, 2003, based on Semiat, 2000 ), the Total Cost of Water (COW) from the Carlsbad plant is about $\$ 0.73 / \mathrm{m}^{3}$, or $\$ 904 /$ acre-foot, equal to the cost estimate in Chaudhry (2003). Therefore, according to Ackerman et al. (2003, p.1):

"This water would be more costly than imported water, which is purchased by local water agencies at $\$ 526$ per acre-foot. A $\$ 250$ per acre-foot subsidy provided by the Metropolitan Water District will help defray some of the cost difference." 
Table 2 The Encina Power Station

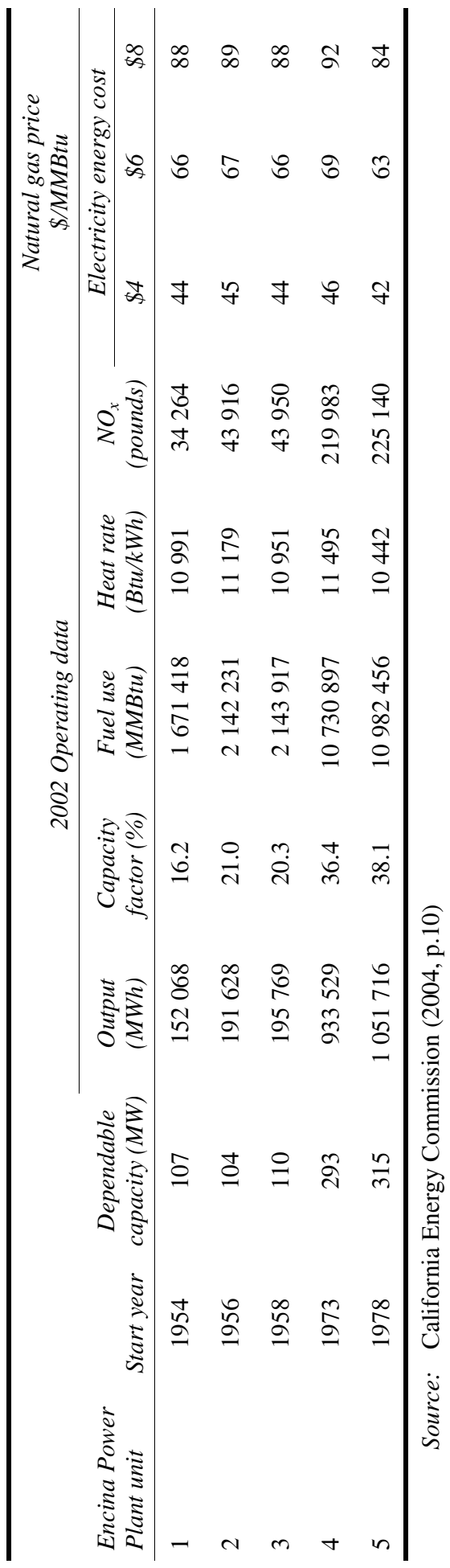


Table 3 Energy costs for Carlsbad Desalination Plant

\begin{tabular}{|c|c|c|c|c|}
\hline \multicolumn{2}{|c|}{ Average electric demand } & \multicolumn{2}{|c|}{$30 \mathrm{MW}$} & \\
\hline \multicolumn{2}{|c|}{ Capacity factor of RO plant } & \multicolumn{2}{|c|}{$90 \%$ daily } & \\
\hline \multicolumn{2}{|c|}{ Average MWh per day } & \multicolumn{2}{|c|}{$648 \mathrm{MWh}$} & \\
\hline \multirow[t]{2}{*}{ Unit energy use = } & & $\begin{array}{c}\mathrm{m}^{3} / \mathrm{MWh} \\
292\end{array}$ & $\begin{array}{c}\mathrm{kgal} / \mathrm{kWh} \\
77\end{array}$ & $\begin{array}{c}\text { Acre-feet/MWh } \\
237\end{array}$ \\
\hline & \multicolumn{4}{|c|}{ Energy cost $=E C$} \\
\hline Electricity price & $\$ / M W h$ & $\$ / m^{3}$ & $\$ / \mathrm{kgal}$ & $\$$ /acre-foot \\
\hline $\mathrm{p}(\mathrm{t})=$ & 30.00 & 0.103 & 0.389 & 127 \\
\hline $\mathrm{p}(\mathrm{t})=$ & 40.00 & 0.137 & 0.518 & 169 \\
\hline $\mathrm{p}(\mathrm{t})=$ & 50.00 & 0.171 & 0.648 & 211 \\
\hline $\mathrm{p}(\mathrm{t})=$ & 60.00 & 0.205 & 0.778 & 253 \\
\hline $\mathrm{p}(\mathrm{t})=$ & 70.00 & 0.240 & 0.907 & 296 \\
\hline $\mathrm{p}(\mathrm{t})=$ & 75.00 & 0.257 & 0.972 & 317 \\
\hline$p(t)=$ & 80.00 & 0.274 & 1.037 & 338 \\
\hline $\mathrm{p}(\mathrm{t})=$ & 90.00 & 0.308 & 1.166 & 380 \\
\hline $\mathrm{p}(\mathrm{t})=$ & 100.00 & 0.342 & 1.296 & 422 \\
\hline
\end{tabular}

On the other hand, Chaudhry's cost estimate was done before the price of fossil fuels doubled. Further, the cost of electric power in San Diego County (which borders Mexico) is considerably higher than the rest of California due to its isolation from electrical and natural gas grids (because there is little electricity or natural gas trade between Mexico and California). At a cost of $\$ 8.44 / \mathrm{GJ}$ ( $\$ 8 / \mathrm{MMBtu})$, the cost of electricity at Encina would be greater than $\$ 84 / \mathrm{MWh}$ (see Table 2). At $\$ 80 / \mathrm{MWh}$ (SDG\&E sells electricity to industrial retail customers at $\$ 105 / \mathrm{MWh}$, see California Energy Commission, 2003, p.12), the EC increases to $\$ 0.274 / \mathrm{m}^{3}$ (see Table 3). (The cost of power from the Encina is high because of its high heat rate, its low capacity factor, and its high emissions of $\mathrm{NO}_{\mathrm{x}}$.) Assuming O\&M costs of 19\%, the total cost of desalinated water from the Carlsbad plant is closer to $\$ 0.90 / \mathrm{m}^{3}$ with current energy prices (see Table 4 ).

Table 4 COW for Carlsbad Desalination Plant, $\$ / \mathrm{m}^{3}$

\begin{tabular}{ccccccccc}
\hline$\$ / M W h$ & $r=3 \%$ & $5 \%$ & $6 \%$ & $8 \%$ & $9 \%$ & $10 \%$ & $12 \%$ & $15 \%$ \\
\hline$\$ 30.00$ & $\$ 0.47$ & $\$ 0.54$ & $\$ 0.58$ & $\$ 0.65$ & $\$ 0.69$ & $\$ 0.73$ & $\$ 0.82$ & $\$ 0.95$ \\
$\$ 40.00$ & $\$ 0.51$ & $\$ 0.58$ & $\$ 0.62$ & $\$ 0.69$ & $\$ 0.73$ & $\$ 0.77$ & $\$ 0.86$ & $\$ 0.99$ \\
$\$ 50.00$ & $\$ 0.55$ & $\$ 0.62$ & $\$ 0.66$ & $\$ 0.73$ & $\$ 0.77$ & $\$ 0.82$ & $\$ 0.90$ & $\$ 1.04$ \\
$\$ 60.00$ & $\$ 0.59$ & $\$ 0.66$ & $\$ 0.70$ & $\$ 0.77$ & $\$ 0.81$ & $\$ 0.86$ & $\$ 0.94$ & $\$ 1.08$ \\
$\$ 70.00$ & $\$ 0.64$ & $\$ 0.70$ & $\$ 0.74$ & $\$ 0.82$ & $\$ 0.86$ & $\$ 0.90$ & $\$ 0.98$ & $\$ 1.12$ \\
$\$ 80.00$ & $\$ 0.68$ & $\$ 0.74$ & $\$ 0.78$ & $\$ 0.86$ & $\$ 0.90$ & $\$ 0.94$ & $\$ 1.02$ & $\$ 1.16$ \\
$\$ 90.00$ & $\$ 0.72$ & $\$ 0.78$ & $\$ 0.82$ & $\$ 0.90$ & $\$ 0.94$ & $\$ 0.98$ & $\$ 1.06$ & $\$ 1.20$ \\
$\$ 100.00$ & $\$ 0.76$ & $\$ 0.83$ & $\$ 0.86$ & $\$ 0.94$ & $\$ 0.98$ & $\$ 1.02$ & $\$ 1.10$ & $\$ 1.24$ \\
\hline
\end{tabular}


Is there a cheaper, cleaner source of electricity that would reduce the cost of desalination? Consider San Diego's General Atomics' Modular Helium Reactors (MHRs): the Gas Turbine, GT-MHR, and the Process Heat, PH-MHR (used, for example, to produce hydrogen), see Table 5, and the proposed Very High Temperature (Gas) Reactor (VHTR). In the next section, the 'Hydrogen-MHR' refers to a VHTR producing hydrogen.

Table 5 Plant and O\&M characteristics of the GT-MHR and PH-MHR

\begin{tabular}{lcc}
\hline Plant characteristics & & \\
\hline Reactor type (both versions with four units per plant) & GT-MHR & PH-MHR \\
Net thermal capacity (MWth) & 2400 & 2400 \\
Net electric capacity (MWe/MWe equivalent) & 1145 & 1008 \\
Thermodynamic efficiency (\%) & 47.7 & 42 \\
Capacity factor of the reactor (\%) & 90 & 90 \\
Economic life (years) & 40 & 40 \\
Construction duration (years) for four units & 5 & 5 \\
Contingency rate (from EMWG 2005 Guidelines) (\%) & 15 & 15 \\
Real discount rate for IDC and amortisation & 10 & 10 \\
\hline
\end{tabular}

\section{Estimating the cost of electricity, hydrogen, and water from a modular helium reactor}

What are reasonable electricity, hydrogen, and water cost estimates for members of the MHR family? First, regarding the cost of electricity, Bogart and Schultz (2004) assume \$29/MWh from the GT-MHR, following La Bar (2002). Rothwell et al. (2005) show that after making adjustments following the EMWG (2005) Guidelines, the levelised cost for the GT-MHR is closer to $\$ 31 / \mathrm{MWh}$. (These are Nth-of-a-Kind costs.) See Table 6. At either $\$ 29 / \mathrm{MWh}$ or $\$ 31 / \mathrm{MWh}$, the GT-MHR is likely to be competitive in the electricity market.

Table 6 Levelised cost for NOAK General Atomics four-unit MHR (2002 dollars)

\begin{tabular}{lcccc}
\hline & GT-MHR & $\begin{array}{c}\text { GT-MHR } \\
\text { adjusted }\end{array}$ & $\begin{array}{c}\text { PH-MHR } \\
\text { Capital recovery factor }(\%)\end{array}$ & $\begin{array}{c}\text { PH-MHR } \\
\text { adjusted }\end{array}$ \\
\hline Capital cost & $\begin{array}{l}\text { (\$/MWh) } \\
\text { Fuel cycle cost }\end{array}$ & $\begin{array}{c}10.23 \% \\
(\$ / \mathrm{MWh})\end{array}$ & $\begin{array}{c}10.50 \% \\
(\$ / \mathrm{GJ})\end{array}$ & $\begin{array}{c}10.23 \% \\
(\$ / \mathrm{GJ})\end{array}$ \\
O\&M cost & 16.15 & 20.10 & 6.90 & 9.41 \\
D\&D & 7.40 & 7.40 & 2.31 & 2.31 \\
Cost of electricity & 3.34 & 3.34 & 3.01 & 3.01 \\
Cost of H2 $(\$ / \mathrm{GJ})$ & 0.00 & 0.07 & 0.00 & 0.02 \\
Cost of H2 $(\$ / \mathrm{kg})$ & 26.89 & 30.91 & & \\
\hline
\end{tabular}

Source: See Rothwell et al. (2005) 
Second, Bogart and Schultz do not discuss the cost of hydrogen from the PH-MHR or the H2-MHR. However, estimates of the cost of hydrogen with the MHR were published in Brown et al. (2003). The cost estimates were carried out assuming that the process adopted for hydrogen production is the thermally driven sulphur-iodine (S-I) technology (a technology selected after an extensive search, see Brown et al., 2003, Ch.2).

Rothwell et al. (2005) apply the EMWG (2005) Guidelines to the PH-MHR cost estimates. Table 6 presents the results of the levelised cost calculations from Rothwell et al. (2005) for a 40-year economic life. The annual production of 200000 tonnes of hydrogen per year $\left(6.2 \mathrm{M} \mathrm{m}^{3} /\right.$ day maximum capacity) is from Brown et al. (2003, Tables 3-16). The cost of hydrogen is $\$ 12.58 / \mathrm{GJ}$ under the assumptions in Brown et al. (2003), with a capital recovery factor of $10.5 \%$. With the Guidelines adjustments, the cost is $\$ 15.11 / G J$ (see last column, last line in Table 6), which is between the values of $\$ 13.90 / \mathrm{GJ}$ and $\$ 16.50 / \mathrm{GJ}$ for different capital recovery factors in Brown et al. (2003, p.3-38). A reasonable range for a Nth-of-a-Kind MHR with the S-I technology is $\$ 12-\$ 16 /$ GJ. But as Rothwell and Williams (2006) point out, this cost of hydrogen is competitive with the production of hydrogen from natural gas if high natural gas prices continue or if carbon taxes are imposed, and only if development of the S-I process and the VHTR are successful.

Third, regarding the COW from a MHR, Bogart and Schultz (2004) calculate the cost of producing water at a $360000 \mathrm{~m}^{3} /$ day facility using either RO or MED with either the GT-MHR or the H2-MHR, i.e., at twice the size of the Carlsbad project. They calculated these costs based on information and scaling from the Tampa Bay RO plant of 95000 $\mathrm{m}^{3} /$ day and the Taweelah A1 MED Plant of $240000 \mathrm{~m}^{3} /$ day. They assume (1) that both the GT-MHR and the H2-MHR "have a comparable heat rejection power and temperature for a four module facility", (p.8) and thus do not make a distinction between the two technologies, and (2) that heat to the desalination facility has no cost ('free heat'). They assume two costs of electricity: $\$ 29 / \mathrm{MWh}$ for the cost of electricity from the GT-MHR (see La Bar, 2002) and $\$ 58 / \mathrm{MWh}$ for the price of electricity stated by the owners of the Tampa Bay facility.

Table 7 presents their sensitivity analysis. For high FCR, the COW with RO is less than with MED. With low FCR and high costs of electricity, the COW with MED is less than with RO. Given that the high cost of electricity is more probable, whether MED is cheaper than RO depends on the FCR. Therefore, Bogart and Schultz (2004, pp.8-9) conclude:

"The GT-MHR and the Hydrogen-MHR are unique in that they can operate at
efficiencies sufficiently high that desalination steam can be produced with a
negligible effect on efficiency. Likewise, other than in certain 'regions of
concern' regarding nuclear proliferation, their safety features appear to permit
siting virtually anywhere. A MED plant coupled with a Hydrogen-MHR
appears to be the most attractive desalination option at this time.",

However, the GT-MHR is likely to be competitive and successful in the electricity market, and the development of the VHTR is likely to depend on the commercialisation of the GT-MHR. Before concluding that a MED plant coupled with a Hydrogen-MHR is the most attractive desalination option, Bogart and Schultz's results can be compared with those from the International Atomic Energy Agency's (IAEA) Desalination Economic Evaluation Program (DEEP), originally developed by General Atomics in 1997 (see Methnani, 2004 on IAEA, 1997). The next section uses DEEP to evaluate desalination options in San Diego County. 
Table 7 COW ( $\$ / \mathrm{kgal})$ for RO and MED for either MHR

\begin{tabular}{lcccc}
\hline & $F C R_{I}$ & $F C R_{2}$ & $F C R_{I}$ & $F C R_{2}$ \\
\hline Fixed charge rate (\%) & 6 & 15 & 6 & 15 \\
Cost of electricity (\$/MWh) & $\$ 29$ & $\$ 29$ & $\$ 58$ & $\$ 58$ \\
Reverse osmosis & $\$ 1.53$ & $\$ 2.25$ & $\$ 1.85$ & $\$ 2.57$ \\
Multi-effect distillation & $\$ 1.54$ & $\$ 2.49$ & $\$ 1.72$ & $\$ 2.67$ \\
\hline
\end{tabular}

Source: See Bogart and Schultz (2004)

\section{Using IAEA's DEEP 3.0 to evaluate desalination options in San Diego County}

The IAEA sponsored the development of the DEEP to aid member countries with the evaluation of nuclear energy systems in the production of desalinated water. While the spreadsheet program gives many nuclear energy and desalination combinations, this section evaluates only three nuclear energy technologies: the System 80+ Pressurized Water Reactor (PWR) as an example of the 'Nuclear Steam Cycle', the GT-MHR as an example of the 'Nuclear Brayton Cycle', and Encina Power Station as an example of the 'Oil Steam Cycle'. The characteristics of these technologies are presented in Table 8. Characteristics of Encina are taken as representative of an oil steam-turbine generator. (A conventional natural gas steam-turbine plant is not available in DEEP.) The cost of $\$ 516 / \mathrm{kWe}(\$ 2002)$ and a contingency of 5\% were taken from US DOE-EIA (2005) for a 'conventional gas/oil combined cycle'. Desalination technology characteristics for DEEP input are presented in Table 9. See IAEA (2006).

Table 8 Characteristics of energy production technologies for DEEP

\begin{tabular}{llccc}
\hline DEEP energy plant production and cost data & & $P W R$ & $M H R$ & $E P S$ \\
\hline Net electric power & $\mathrm{MW}$ & 1256 & 1145 & 929 \\
Gross thermal power & $\mathrm{MW}$ & 3817 & 2400 & 2933 \\
Specific construction cost & $\$ / \mathrm{kW}$ & $\$ 1,669$ & $\$ 1,087$ & $\$ 516$ \\
Additional site-related construction cost & $\$ / \mathrm{kW}$ & 0 & 0 & 0 \\
Energy plant contingency factor & $\%$ & $10 \%$ & $15 \%$ & $5 \%$ \\
Construction lead time & months & 72 & 60 & 36 \\
Total specific construction cost & $\$ / \mathrm{kW}$ & $\$ 1,836$ & $\$ 1,250$ & $\$ 542$ \\
Total construction cost & $\mathrm{M} \$$ & $\$ 2,306$ & $\$ 1,431$ & $\$ 503$ \\
Interest During Construction (IDC) at 10\% & $\mathrm{M} \$$ & $\$ 763$ & $\$ 385$ & $\$ 77$ \\
Total plant investment & $\mathrm{M} \$$ & $\$ 3,069$ & $\$ 1,775$ & $\$ 581$ \\
Specific investment cost & $\$ / \mathrm{kW}$ & $\$ 2,444$ & $\$ 1,550$ & $\$ 625$ \\
Specific O\&M cost & $\$ / \mathrm{MWh}$ & $\$ 7.50$ & $\$ 3.34$ & $\$ 2.07$ \\
Specific fuel cost (with $\$ 50 /$ barrel oil) & $\$ / \mathrm{MWh}$ & $\$ 5.00$ & $\$ 7.40$ & $\$ 107$ \\
Fuel annual real escalation & $\% / \mathrm{a}$ & $0 \%$ & $0 \%$ & $0 \%$ \\
Nuclear decommissioning cost factor & $\%$ & $30 \%$ & $30 \%$ & $0 \%$ \\
Specific decommissioning cost & $\$ / \mathrm{MWh}$ & $\$ 501$ & $\$ 326$ & $\$ 0$ \\
Annual levelised decommissioning cost & $\mathrm{M} \$ / \mathrm{a}$ & $\$ 94$ & $\$ 54$ & $\$ 0$ \\
\hline
\end{tabular}

Source: DEEP3.0 input 
Table 9 Desalination technology characteristics for DEEP

\begin{tabular}{lccc}
\hline DEEP desalination technology type & & $R O$ & MED \\
\hline Required capacity & $\mathrm{m}^{3} / \mathrm{d}$ & 190000 & 190000 \\
Total construction cost & $\$ \mathrm{M}$ & $\$ 272$ & \\
Total specific base cost & $\$ /\left(\mathrm{m}^{3} / \mathrm{d}\right)$ & & $\$ 1,108$ \\
Feed temperature & ${ }^{\circ} \mathrm{C}$ & 18 & 18 \\
Seawater feed salinity & $\mathrm{ppm}$ & 33500 & 33500 \\
\hline
\end{tabular}

Source: DEEP3.0 input

The characteristics of the System 80+ are used because it is one of four advanced light water reactor designs certified by the US NRC, and because the largest nuclear power plant in the USA, Palo Verde in Arizona (with three units able to produce $3900 \mathrm{MW}$, gross) uses the precursor design to the System 80+. (Palo Verde supplies power to San Diego County and SDG\&E's service territory.) Further, a precursor to Palo Verde was built at San Onofre Nuclear Generating Station (SONGS) in San Clemente, California, 30 minutes north of Carlsbad. A single unit System 80+ PWR built on the SONGS site could replace San Onofre Unit 1, retired since 1992, providing 3817 MWth of thermal energy and $1256 \mathrm{MWe}$ of electrical generation and water desalination. The 'specific construction cost' of $\$ 1,669 / \mathrm{kWe}$, the contingency of $10 \%$, and the O\&M cost of $\$ 7.50 / \mathrm{MWh}$ are from US DOE-EIA (2005). The fuel cost of $\$ 5 / \mathrm{MWh}$ is equal to the current fuel costs at SONGS and Palo Verde.

The characteristics of the GT-MHR and PH-MHR in Table 5 were taken from Rothwell et al. (2005). Because DEEP did not offer an option to couple a nuclear hydrogen generator with a desalination technology, only the characteristics of the GT-MHR are considered, i.e., a gross thermal power of $2400 \mathrm{MWth}$, a net electric generation of $1145 \mathrm{MWe}$, and a specific investment cost of $\$ 1,550 / \mathrm{kWe}$.

Tables 10 (assuming a 5\% discount rate) and 11 (assuming a 10\% discount rate) present the results of the DEEP analysis with a 'purchased electricity cost' of $\$ 58 / \mathrm{MWh}$, equal to the price of electricity assumed in Bogart and Schultz (2004) with no backup heat source. The DEEP program yields cost estimates almost identical to those discussed above for the RO option with a fossil-fired power plant similar to Encina. (Also, these results are nearly identical with those in Nisan and Dardour, 2006.) The fixed charge cost at $5 \%\left(\$ 0.358 / \mathrm{m}^{3}\right)$ is nearly equal to the fixed cost per $\mathrm{m}^{3}$ at $5 \%$ in Table 1 (i.e., $\$ 0.351 / \mathrm{m}^{3}$, i.e., a difference of $2 \%$ ). The plant plus purchased electricity cost $\left(\$ 0.257 / \mathrm{m}^{3}=\$ 0.236 / \mathrm{m}^{3}+\$ 0.021 / \mathrm{m}^{3}\right)$ is equal to the energy cost of $\$ 0.257 / \mathrm{m}^{3}$ in Table 3 at an electricity price of $\$ 75 / \mathrm{MWh}$ (compared to a calculated value of $\$ 82.74 / \mathrm{MWh}$ in Table 10). The O\&M cost of $\$ 0.17 / \mathrm{m}^{3}$ is $23 \%$ of the COW in Table 10 , compared with the assumed percentage of $19 \%$ implicit in Table 4 . Therefore, the calculations done here to replicate Chaudhry (2003) are confirmed by DEEP 'within the error bars of the analysis'. 
Table 10 DEEP results on the COW (5\% discount rate)

\begin{tabular}{lccccccc}
\hline $\begin{array}{l}\text { Purchased electricity cost } \\
\text { Interest rate }\end{array}$ & \multicolumn{2}{c}{$\$ 58$} & $\$ / M W h$ & & & & \\
\hline & & & & & & \\
Specific water costs & & $R P S$ & $E P S$ & $P W R$ & $P W R$ & $M H R$ & $M H R$ \\
\hline Fixed charge cost & $\$ / \mathrm{m}^{3}$ & 0.358 & 0.377 & 0.358 & 0.356 & 0.358 & 0.356 \\
Heat cost & $\$ / \mathrm{m}^{3}$ & & 0.559 & & 0.152 & & \\
Plant electricity cost & $\$ / \mathrm{m}^{3}$ & 0.236 & 0.310 & 0.099 & 0.095 & 0.077 & 0.074 \\
Purchased electricity cost & $\$ / \mathrm{m}^{3}$ & 0.021 & & 0.011 & & 0.011 & \\
O\&M cost & $\$ / \mathrm{m}^{3}$ & 0.170 & 0.132 & 0.170 & 0.129 & 0.170 & 0.129 \\
Total specific water cost (COW) & $\$ / \mathrm{m}^{3}$ & $\$ 0.79$ & $\$ 1.38$ & $\$ 0.64$ & $\$ 0.73$ & $\$ 0.62$ & $\$ 0.56$ \\
Total specific water cost (COW) & $\$ / \mathrm{kGal}$ & $\$ 2.97$ & $\$ 5.21$ & $\$ 2.42$ & $\$ 2.77$ & $\$ 2.33$ & $\$ 2.12$ \\
Total specific water cost $(\mathrm{COW})$ & $\$ / \mathrm{acre}$ & $\$ 969$ & $\$ 1,698$ & $\$ 788$ & $\$ 903$ & $\$ 761$ & $\$ 690$ \\
Fixed charge cost & $\$ / \mathrm{MWh}$ & $\$ 4.78$ & $\$ 4.78$ & $\$ 15.71$ & $\$ 15.71$ & $\$ 11.46$ & $\$ 11.46$ \\
Fuel cost & $\$ / \mathrm{MWh}$ & $\$ 75.89$ & $\$ 106.60$ & $\$ 5.00$ & $\$ 5.00$ & $\$ 7.40$ & $\$ 7.40$ \\
O\&M cost & $\$ / \mathrm{MWh}$ & $\$ 2.07$ & $\$ 2.07$ & $\$ 7.50$ & $\$ 7.50$ & $\$ 3.34$ & $\$ 3.34$ \\
Decommissioning cost & $\$ / \mathrm{MWh}$ & & & $\$ 4.71$ & $\$ 4.71$ & $\$ 3.44$ & $\$ 3.44$ \\
Levelised electricity cost & $\$ / \mathrm{MWh}$ & $\$ 82.74$ & $\$ 113.45$ & $\$ 32.92$ & $\$ 32.92$ & $\$ 25.64$ & $\$ 25.64$ \\
\hline
\end{tabular}

Source: DEEP3.0 output

However, unlike Bogart and Schultz (2004), DEEP finds the COW from a MED plant cheaper than from an RO plant because of the 'free heat' from a GT-MHR. The MED and RO plants have approximately the same fixed charge for either nuclear technology. However, because there is lower quality 'waste heat' from the PWR than from the MHR, the heat cost of the MED is higher for the PWR than the MHR. The plant electricity cost is also higher for the PWR than the MHR (due to its higher efficiency, hence lower capital costs). In addition, the electricity cost difference increases with the discount rate. ${ }^{3}$ Therefore, it is the cost of 'free heat' that drives the DEEP results favouring the MED for the GT-MHR.

The DEEP programme assumes 'free heat' under the power credit method, see IAEA (2000). Under an exergy-based pricing mechanism (see Nisan and Dardour, 2006), the cost of heat would increase. Given that the cost of heat varies between $\$ 0.15 / \mathrm{m}^{3}$ in Table 10 to $\$ 0.25 / \mathrm{m}^{3}$ in Table 11, an increase in the cost of heat for MED desalination at the MHR of $\$ 0.06 / \mathrm{m}^{3}$ would equate the cost of water from either the MHR-RO and the MHR-MED whether the interest rate is $5 \%$ or $10 \%$. But are the differences between the cost of water from the PWR significantly different from the cost from the MHR?

Assuming:

- an overall contingency in the cost of water (not simply the construction cost of the desalination plant, as in DEEP) is $10 \%$

- that the standard error of the estimate is equal to the contingency, following Rothwell (2005) 
- that the standard errors of the estimates are independent

- then the distribution of the differences between the cost of water estimates is normal.

Tables 12 and 13 calculate whether these differences are statistically significant with a $5 \%$ discount rate (Table 12 following results in Table 10) and with a $10 \%$ discount rate (Table 13 following the results in Table 11).

Table 11 DEEP results on the cost of water (10\% discount rate)

\begin{tabular}{|c|c|c|c|c|c|c|c|}
\hline \multirow{2}{*}{$\begin{array}{l}\text { Purchased electricity cost } \\
\text { Interest rate }\end{array}$} & & $\$ 58$ & \multicolumn{5}{|l|}{$\$ / M W h$} \\
\hline & & $10 \%$ & & & & & \\
\hline Specific water costs & & $\begin{array}{c}E P S \\
R O\end{array}$ & $\begin{array}{c}E P S \\
M E D\end{array}$ & $\begin{array}{c}P W R \\
R O\end{array}$ & $\begin{array}{l}P W R \\
M E D\end{array}$ & $\begin{array}{c}M H R \\
R O\end{array}$ & $\begin{array}{l}M H R \\
M E D\end{array}$ \\
\hline Fixed charge cost & $\$ / \mathrm{m}^{3}$ & 0.537 & 0.565 & 0.537 & 0.533 & 0.537 & 0.533 \\
\hline Heat cost & $\$ / \mathrm{m}^{3}$ & & 0.541 & & 0.248 & & \\
\hline Plant electricity cost & $\$ / \mathrm{m}^{3}$ & 0.247 & 0.299 & 0.162 & 0.155 & 0.111 & 0.106 \\
\hline Purchased electricity cost & $\$ / \mathrm{m}^{3}$ & 0.021 & & 0.011 & & 0.011 & \\
\hline O\&M cost & $\$ / \mathrm{m}^{3}$ & 0.170 & 0.132 & 0.170 & 0.129 & 0.170 & 0.129 \\
\hline Total specific water cost & $\$ / \mathrm{m}^{3}$ & $\$ 0.98$ & $\$ 1.54$ & $\$ 0.88$ & $\$ 1.07$ & $\$ 0.83$ & $\$ 0.77$ \\
\hline Total specific water cost & $\$ / \mathrm{kgal}$ & $\$ 3.69$ & $\$ 5.81$ & $\$ 3.33$ & $\$ 4.03$ & $\$ 3.14$ & $\$ 2.91$ \\
\hline Total specific water cost & \$/acre & $\$ 1,202$ & $\$ 1,894$ & $\$ 1,085$ & $\$ 1,314$ & $\$ 1,023$ & $\$ 948$ \\
\hline Fixed charge cost & $\$ / M W h$ & $\$ 8.70$ & $\$ 8.70$ & $\$ 31.69$ & $\$ 31.69$ & $\$ 20.11$ & $\$ 20.11$ \\
\hline Fuel cost & $\$ / \mathrm{MWh}$ & $\$ 75.89$ & $\$ 98.90$ & $\$ 5.00$ & $\$ 5.00$ & $\$ 7.40$ & $\$ 7.40$ \\
\hline O\&M cost & $\$ / M W h$ & $\$ 2.07$ & $\$ 2.07$ & $\$ 7.50$ & $\$ 7.50$ & $\$ 3.34$ & $\$ 3.34$ \\
\hline Decommissioning cost & $\$ / M W h$ & & & $\$ 9.51$ & $\$ 9.51$ & $\$ 6.03$ & $\$ 6.03$ \\
\hline Levelised electricity cost & $\$ / M W h$ & $\$ 86.67$ & $\$ 109.67$ & $\$ 53.70$ & $\$ 53.70$ & $\$ 36.88$ & $\$ 36.88$ \\
\hline
\end{tabular}

Source: DEEP3.0 output

Table 12 Testing differences in DEEP cost of water (5\% discount rate)

\begin{tabular}{lccc}
\hline \multicolumn{3}{c}{ Std dev = contingency $=10 \%$} & \\
\hline Standard error of estimate & & & \\
PWR & PWR & MHR & MHR \\
RO & MED & RO & MED \\
\$0.064 & $\$ 0.073$ & $\$ 0.062$ & $\$ 0.056$ \\
Standard error of difference & & MHR RO & MHR MED \\
PWR RO & & 0.089 & 0.085 \\
PWR MED & 0.096 & 0.092 \\
Z-score & & MHR RO & MHR MED \\
PWR RO & 0.248 & 0.899 \\
PWR MED & 1.203 & 1.878 \\
\hline
\end{tabular}


Table 13 Testing differences in DEEP cost of water (10\% discount rate)

\begin{tabular}{lccc}
\hline & \multicolumn{2}{c}{ Std dev = contingency $=10 \%$} & \\
\hline Standard error of estimate & & & \\
PWR & PWR & MHR & MHR \\
RO & MED & RO & MED \\
\$0.088 & $\$ 0.107$ & $\$ 0.083$ & $\$ 0.077$ \\
Standard error of difference & & MHR RO & MHR MED \\
PWR RO & & 0.121 & 0.117 \\
PWR MED & 0.135 & 0.131 \\
Z-score & & MHR RO & MHR MED \\
PWR RO & 0.420 & 0.920 \\
PWR MED & 1.747 & 2.256 \\
\hline
\end{tabular}

With a $5 \%$ discount rate and a $10 \%$ contingency, the standard errors for the estimate of PWR-RO, PWR-MED, MHR-RO, and MHR-MED are \$0.064, \$0.073, \$0.062, and $\$ 0.056$, following the Total Specific Water Cost $\left(\$ / \mathrm{m}^{3}\right)$ in Table 10. The standard error of the differences are given in the second set of rows in Table 12. The Z-score (the difference between the cost of water for each technology divided by the standard error of the differences) is given in the third set of rows in Table 12. The Z-score follows a normal distribution. There is no significant difference between the cost of water from PWR-RO (\$0.64) and MHR-RO (\$0.62) or MHR-MED (\$0.56) or between the cost of water from PWR-MED (\$0.73) and MHR-RO (\$0.62). However, there is a significant difference between PWR-MED (\$0.73) and MHR-MED (\$0.56).

With a $10 \%$ discount rate and a $10 \%$ contingency, see Table 13, following the same reasoning, there is no significant difference between PWR-RO (\$0.88) and MHR-RO (\$0.83) or MHR-MED (\$0.77). However, there is a significant difference between PWR-MED (\$1.07) and MHR-RO (\$0.83) and MHR-MED (\$0.77). Therefore, we can conclude that MHR-MED is significantly cheaper than PWR-MED, but we cannot conclude that either MHR-MED or MHR-RO is significantly cheaper than PWR-RO based on the results of DEEP.

Further, the costs discussed here, and in Bogart and Schultz (2004), are for Nth-of-a-Kind (NOAK) units. Following General Atomics (2002, p.14), the overnight construction cost of the First-of-a-Kind (FOAK) MHR units could be 50\% higher than for the NOAK units. Therefore, the cost of water with a NOAK PWR with RO could be less than the cost of water with a FOAK MHR with either RO or MED. Finally, the construction of a NOAK PWR (third generation) is likely to begin within this decade; the NOAK MHR will unlikely be deployed in the next decade.

Until construction on the next generation nuclear power plants begins, the public acceptance of nuclear power desalination could be tested with the construction of a $190000 \mathrm{~m}^{3} /$ day RO plant at an existing light water reactor. This could be an expansion of the exiting RO plant at Diablo Canyon (on the central Californian coast) or the construction of another RO facility at San Onofre. Future research should evaluate the economics and public acceptance of drinking water from these two sites: 
1 using nuclear power plant cooling water with lower energy costs

2 adding a heat exchanger with higher capital costs. (The optimal RO capacity should consider the savings of using off-peak nuclear electricity with a multi-day capacity reservoir.)

This research could then be generalised to nuclear power plants on the Atlantic coast in the USA and Europe.

\section{Acknowledgements}

I thank E. Bertel, S.L. Bogart, F. Depisch, J. Jeffrey, A. Maïsseu, M. Methnani, B.M. Misra, S. Nisan, P. Peterson, W. Rasin, J. Redding, K. Schultz, P. Tewari, K. Williams, and members of the Economic Modeling Working Group of the Generation IV International Forum $(G I F)$, for their encouragement, data, comments, and references. This paper reflects the views and conclusions of the author and not those of the employers, sponsors, publishers, EMWG, or GIF.

\section{References}

Ackerman, L., Bannon, J., Leophairatana, A. and Yamada, K. (2003) Assessment of Seawater Desalination as a Water Supply Strategy for San Diego County, Donald Bren School of Environmental Science and Management, University of California, Santa Barbara. http://www.bren.ucsb.edu/research/2003Group_Projects/lesa/Final/lesa_brief.pdf.

Bogart, S.L. (2003) Water Desalination as a Possible Opportunity for the GT-and H2-MHR, White Paper, Australian Institute of Energy, www.aie.org.au/syd/downloads/Desalination $\% 20$ White\%20Paper.doc.

Bogart, S.L. and Schultz, K.R. (2004) 'Water desalination as a possible opportunity for the GT- and H2-MHR', Proceedings of the ICAPP '04, Pittsburgh, PA, USA, 13 June, http://www.aie.org.au/syd/downloads/Desalination\%20using\%20the\%20MHR.pdf.

Brown, L.C., Besenbruch, Lentsch, R.D., Schultz, K.R., Funk, J.E., Pickard, P.S., Marshall, A.C. and Showalter, S.K. (2003) 'High efficiency generation of hydrogen fuels using nuclear power', General Atomics, GA-A24285, June, http://web.gat.com/pubs-ext/AnnSemiannETC/ A24285.pdf.

California Energy Commission (2003) California Investor-Owned Utilities Retail Electricity Price Outlook 2003-2013, Sacramento, California, 11 February.

California Energy Commission (2004) Resource, Reliability and Environmental Concerns of Aging Power Plant Operations and Retirements, Sacramento, California, 13 August.

Chaudhry, S. (2003) Unit Cost of Desalination, California Desalination Task Force, California Energy Commission, 20 July.

City of Carlsbad (2005) Environmental Impact Report on Poseidon Resources' Carlsbad Seawater Desalination Plant, City of Carlsbad, California, December.

Dougherty, C. (2004) 'Several local businesses may benefit from proposed Carlsbad Desalination Plant', San Diego Union-Tribune, 21 March, http://www.signonsandiego.com/news/ northcounty/20040321-9999-news_m1m21desal.html.

Economic Modeling Working Group (EMWG) (2005) 'Cost estimating guidelines for Generation IV nuclear energy systems', EMWG of the Generation IV International Forum (GIF), http://nuclear.inel.gov/deliverables/docs/emwgguidelines_rev2.pdf. 
General Atomics (2002) GT-MHR Commercialization Study: Final Technical Report, General Atomics, GA-A24045, July, http://www.osti.gov/bridge/purl.cover.jsp?purl=/797074 -xGJjKA/native/.

International Atomic Energy Agency (IAEA) (1997) Methodology for the Economic Evaluation of Cogeneration/Desalination Options: A User's Manual, IAEA-Computer Manual Series No. 12, Vienna: IAEA.

International Atomic Energy Agency (2000) Introduction of Nuclear Desalination: A Guidebook, Vienna: IAEA, http://www.iaea.org/OurWork/ST/NE/NENP/NPTDS/Projects/nd/tecdocs/trs _400.html.

International Atomic Energy Agency (IAEA) (2006) Desalination Economic Evaluation Program (DEEP-3.0): User's Manual, IAEA-Computer Manual Series No. 19, Vienna: IAEA, http://www-pub.iaea.org/MTCD/publications/PDF/CMS-19_web.pdf.

La Bar, M.P. (2002) 'The gas turbine-modular helium reactor: a promising option for near term deployment', General Atomics, GA-A23952, April.

Methnani, M. (2004) 'DEEP: a tool for evaluating co-generated power and desalination strategies', Desalination, No. 166, pp.11-15.

Nisan, S. and Dardour, S. (2006) 'Economic evaluation of nuclear desalination systems', Presented to the European Desalination Society, Montpellier, France, 21-25 May.

Rothwell, G.S. (1991) 'The optimal time to decommissioning commercial nuclear reactors', Special issue, The Energy Journal, Vol. 12, pp.305-314.

Rothwell, G.S. (2005) 'Cost contingency as the standard deviation of the cost estimate', Cost Engineering, Vol. 47, No. 7, pp.22-25.

Rothwell, G.S. and Williams, K. (2006) 'Is nuclear power competitive producing electricity or hydrogen?', International Journal of Nuclear Hydrogen Production and Applications (forthcoming).

Rothwell, G.S., Bertel, E. and Williams, K. (2005) 'Can nuclear power compete in the hydrogen economy?', Third Information Exchange Meeting on the Nuclear Production of Hydrogen, Oarai, Japan: OECD/NEA, 5-7 October.

Semiat, R. (2000) 'Desalination: present and future', Water International, Vol. 25, No. 1, p.62.

US Department of Energy, Energy Information Administration (US DOE-EIA) (2005) 'Electricity marketing module, Table 38', Assumptions to the Annual Energy Outlook 2004, http://www.eia.doe.gov/oiaf/archive/aeo04/assumption/electricity.html.

Volpi, L. and Nisan, S. (2003) 'Evaluation of desalination costs with DEEP', International Journal of Nuclear Desalination, Vol. 1, No. 3.

Voutchkov, N. (2005) Shared Infrastructure Benefits Desalination Economics, WaterandWastewater.Com, 27 July, http://www.waterandwastewater.com/www_services/ news_center/publish/article_00693.shtml.

\section{Notes}

1 City of Carlsbad (2005, p.243), "All 13 reverse osmosis trains will be of the same water production capacity. Therefore, replacing one train with another will maintain the total desalination plant production at $50 \mathrm{mgd}$ at all times. Additionally, under the proposed design, up to 3 out of the 13 trains can be taken out of service and still produce $50 \mathrm{mgd}$ of fresh water."

2 One of the 'regions of concern' is the high enrichment of the fuel. As fuel, it is highly proliferation resistant. But the uranium is enriched to nearly $20 \%$, i.e., the threshold for 'Special Nuclear Material'. 
3 While the fixed charge for the MHR at $10 \%$ is the same under DEEP and the EMWG Guidelines and the Fuel and O\&M costs for the DEEP analysis come from Table 10, DEEP calculates Decontamination and Decommissioning (D\&D) costs at 30\% of the fixed charge rate. This is equivalent to either assuming that $D \& D$ funds accumulate at no interest or that the interest rate is equal to the real escalation rate of D\&D (see discussion in Rothwell, 1991). In the DEEP analysis, the cost of decommissioning is greater than either Fuel or O\&M for the PWR and greater than O\&M costs for the MHR. Volpi and Nisan (2003) identify problems with the annual decommissioning cost in DEEP, and set decommissioning costs to zero in DEEP so that SEMER and DEEP would yield similar results. SEMER assumes $0.8 \%-1.0 \%$ of overnight construction cost per year for decommissioning.

4 Given that there is only one observation for each cost estimate, the standard error of the estimate is equal to the standard deviation, assumed to be equal to $10 \%$ of the cost estimate. The standard error of the difference of the two cost estimates is the square root of the sum of the variances, i.e., the squares of the standard deviations. Also, assume there is no correlation between these variances. See Tables 12 and 13. 